\title{
Mixed Nanostructured Ti-W Oxides Films for Efficient Electrochromic Windows
}

\author{
Nguyen Nang Dinh,, ${ }^{1}$ Dang Hai Ninh, ${ }^{1}$ Tran Thi Thao, ${ }^{1}$ and Truong Vo-Van ${ }^{2}$ \\ ${ }^{1}$ University of Engineering and Technology, Vietnam National University, Hanoi, 144 Xuan Thuy Street, \\ Cau Giay, Hanoi 10000, Vietnam \\ ${ }^{2}$ Department of Physics, Concordia University, 7141 Sherbrooke Street West, Montreal, QC, Canada H4B 1R6
}

Correspondence should be addressed to Nguyen Nang Dinh, dinhnn@vnu.edu.vn

Received 20 March 2012; Accepted 18 May 2012

Academic Editor: Jai Singh

Copyright (C) 2012 Nguyen Nang Dinh et al. This is an open access article distributed under the Creative Commons Attribution License, which permits unrestricted use, distribution, and reproduction in any medium, provided the original work is properly cited.

\begin{abstract}
With the aim to enhance the electrochromic (EC) efficiency and electrochemical stability of electrochromic devices (ECD), mixed nanostructured $\mathrm{TiO}_{2} / \mathrm{WO}_{3}$ films were prepared by an electrochemical deposition method with the purpose of adding $\mathrm{WO}_{3}$ nanoparticles to porous nanocrystalline doctor-blade $\mathrm{TiO}_{2}\left(\mathrm{nc}-\mathrm{TiO}_{2}\right)$ films. The results of the characterization of electrochromic properties in $1 \mathrm{M} \mathrm{LiClO}_{4}+$ propylene carbonate $\left(\mathrm{LiClO}_{4}+\mathrm{PC}\right)$ of both the nc-TiO2/F-doped tin oxide $(\mathrm{FTO})$ and $\mathrm{WO}_{3} / \mathrm{TiO} / 2 / \mathrm{FTO}$ configurations showed the reversible coloration and bleaching of the ECDs. The response time of the $\mathrm{ECD}^{\mathrm{coloration}}$ of $\mathrm{WO}_{3} /$ $\mathrm{TiO}_{2} / \mathrm{FTO}$ was found to be as small as $2 \mathrm{sec}$, and its coloration efficiency $(\mathrm{CE})$ as high as $35.7 \mathrm{~cm}^{2} \times \mathrm{C}^{-1}$. By inserting $\mathrm{WO}_{3}$ nanoparticles into the porous $\mathrm{TiO}_{2}$ structures, $\mathrm{WO}_{3} / \mathrm{TiO}_{2}$ heterojunctions were formed in the films, consequently enabling both the CE and electrochemical stability of the working electrodes to be considerably enhanced. Since a large-area $\mathrm{WO}_{3} / \mathrm{TiO}_{2}$ can be prepared by the doctor-blade technique followed by the electrochemical deposition process, mixed nanostructured Ti-W oxides electrodes constitute a good candidate for smart window applications, taking advantage of the excellent coloration and stability properties as well as the simple and economical fabrication process involved.
\end{abstract}

\section{Introduction}

Electrochromism is a topic that has attracted a great deal of interest from researchers because of its potential application in various areas (photonics, optics, electronics, architecture, etc.). Electrochromic (EC) properties can be found in almost all the transition-metal oxides, and their properties have been investigated extensively in the last decades [1]. These oxide films can be coloured anodically (Ir, Ni) or cathodically (W, $\mathrm{Mo}$ ); however, $\mathrm{WO}_{3}$ is clearly the preferred material for applications. This is principally due to the fact that $\mathrm{WO}_{3}$ based electrochromic devices (ECDs) have normally a faster response time to a change in voltage and a larger coloration efficiency (CE) as compared to devices based on other electrochromic materials. Recently, Granqvist et al. [2] have made a comprehensive review of nanomaterials for benign indoor environments. In this paper, the authors show the characteristic data for a $5 \times 5 \mathrm{~cm}^{2}$ flexible EC foil incorporating $\mathrm{WO}_{3}$, and $\mathrm{NiO}$ modified by the addition of a wide bandgap oxide such as $\mathrm{MgO}$ or $\mathrm{Al}_{2} \mathrm{O}_{3}$, PMMA-based electrolyte, and ITO films. Durability of the EC devices was demonstrated in performing several tens of thousands of coloration/bleaching cycles, and the device optical properties were found to be unchanged for many hours. To improve further the electrochromic properties, Ti-doped $\mathrm{WO}_{3}$ films were deposited by cosputtering metallic titanium and tungsten in an $\mathrm{Ar} / \mathrm{O}_{2}$ atmosphere [3]. Another way to improve electrochromic properties of thin films is to use nanostructured crystalline films. For instance, nanocrystalline $\mathrm{WO}_{3}$ films were prepared by the organometallic chemical vapour deposition (OMCVD) method using tetra(allyl)tungsten. The size of grains found in these films was estimated by atomic force microscope (AFM) and scanning electron microscope (SEM) to be $20 \div 40 \mathrm{~nm}$. The coloration of $\mathrm{WO}_{3}$ deposited on indium tin oxides (ITO) substrates ( $\mathrm{WO}_{3} / \mathrm{ITO}$ ) in $2 \mathrm{M} \mathrm{HCl}$ was less than $1 \mathrm{sec}$ and the maximum coloration efficiency at $630 \mathrm{~nm}$ was $22 \mathrm{~cm}^{2} \times \mathrm{C}^{-1}$ [4]. However, the $\mathrm{HCl}$ electrolyte is not suitable for practical use. The Au-doped $\mathrm{WO}_{3}$ films were 
made by a dip-coating technique [5]. With fabrication of nanostructured $\mathrm{WO}_{3}$ films, Beydaghyan et al. [6] have shown that porous and thick $\mathrm{WO}_{3}$ films can produce a high $\mathrm{CE}$. The open structure, fast response, and high normal state transmission made them good candidates for use in practical applications. The nanocrystalline $\mathrm{TiO}_{2}$ anatase thin films on ITO, prepared by sol-gel dipping method, exhibited a good reversible coloration and bleaching process [7], but the response time was slow and the electrochromic efficiency was not large. Recently [8], we have shown that by using the so-called "doctor-blade" method, nanoporous $\mathrm{TiO}_{2}$ anatase films on F-doped tin oxide (FTO) substrates (nc-TiO $2 /$ FTO) were prepared for the ECDs with much improved electrochromic response time and coloration efficiency (CE). However, with such porous films, for a long exposed performance time, the durability of the devices was limited, making the resulting ECD less satisfying for smart windows applications. In this work, with the aim to enhance the stability of the EC devices on one hand by making more tightly knitted films, and on the other hand, to improve the CE of the ECD performance with the help of nanostructured heterojunctions of $\mathrm{TiO}_{2} / \mathrm{WO}_{3}$, we combined a doctor-blade technique for preparing large-area films with an electrochemical process for depositing $\mathrm{WO}_{3}$ films into the nanoporous $\mathrm{TiO}_{2}$ structures.

\section{Experimental}

To prepare nanostructured $\mathrm{TiO}_{2}$ films for ECD, a doctorblade technique was used following the process reported in [8]. A glass slide, overcoated with a $0.2 \mu \mathrm{m}$ thick FTO film having a sheet resistance of $15 \Omega$ and a transmittance of $90 \%$, was used as a substrate; the useful area that constitutes the sample studied was of $1 \mathrm{~cm}^{2}$. A colloidal solution of $15 \mathrm{wt} \%$ nanoparticles (15 nm in size) of titanium oxide (Nyacol Products) in water was used. For producing thinner films, we added more distilled water to get ca. $5 \mathrm{wt} \% \mathrm{TiO}_{2}$ and a few drops of the liquid surfactant were added. Then the diluted solution was filled in the slot on the FTO electrode and spread along the tapes. The samples were left for drying during $15 \mathrm{~min}$, then put to a furnace maintained at $450^{\circ} \mathrm{C}$ for 1 hour to recrystallize the $\mathrm{nc}-\mathrm{TiO}_{2}$ films.

To deposit $\mathrm{WO}_{3}$ into nc-TiO $/ \mathrm{FTO}$, the peroxy-tungsten acid solution $\left(\mathrm{H}_{2} \mathrm{~W}_{2} \mathrm{O}_{11}\right)$ was prepared. For this $4.6 \mathrm{~g}$ of high-purity metallic tungsten powder was dissolved in $25 \mathrm{ml}$ $\mathrm{H}_{2} \mathrm{O}_{2}(30 \%)$. The excess $\mathrm{H}_{2} \mathrm{O}_{2}$ was decomposed by putting a large-area $\mathrm{Pt}$ sheet into the solution until gas evolution was stopped. After that, the solution was diluted to $50 \mathrm{mM}$ by addition of water to form $500 \mathrm{~mL}$ of the solution and kept in cool air to avoid decomposition of peroxy tungstate to trioxide and polytungstate [9]. A standard three-electrode cell has been used: the working electrode was F-doped$\mathrm{SnO}_{2}$ coated glass (FTO) with a sheet resistance of $15 \Omega$ the reference electrode was saturated calomel electrode (SCE); a Pt grille was used as counter electrode. By using potentiostat "Auto lab. PGS-30," a potentiostatic method was chosen for film deposition. After their deposition, the films were dried in nitrogen gas. Electrochromic properties of the films were

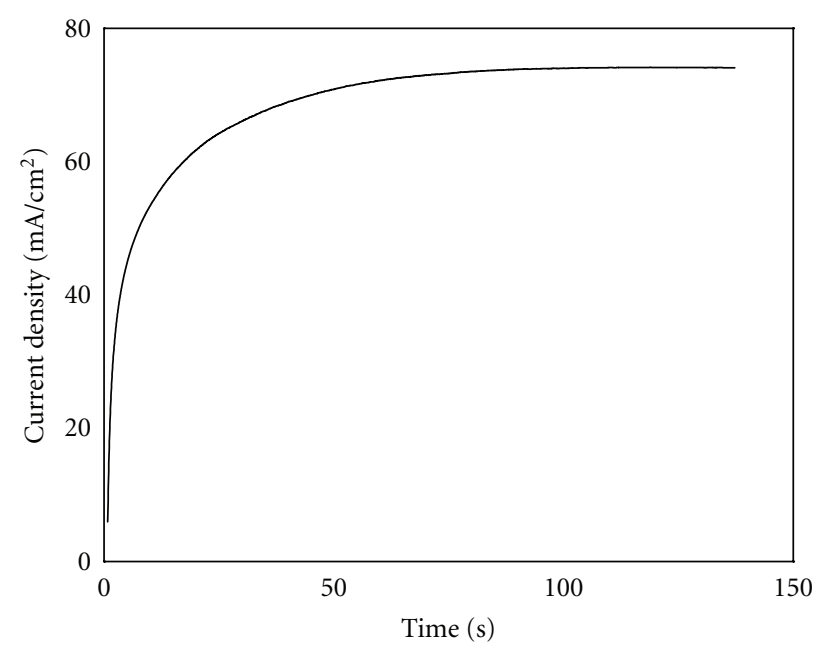

FIGURE 1: The time dependence of the current density during electrochemical deposition of $\mathrm{WO}_{3}$ under a negatively polarized potential of $-1.5 \mathrm{~V} / \mathrm{SCE}$.

determined by cyclic voltametry in electrolytic solutions of $1 \mathrm{M} \mathrm{LiClO}_{4}+$ Propylene carbonate (PC).

The film thickness was measured by an Alpha-step profiler and its surface morphology examined with the help of a field-emission scanning electron microscope (FE-SEM). $\mathrm{X}$-ray diffraction analysis (XRD) was done on a Brucker "Advance-8D" X-ray diffractometer with X-ray Cu wavelength $\lambda=0.154 \mathrm{~nm}$. Electrochemical processes were carriedout on the same potentiostat. All measurements were executed at room temperature.

By using a JASCO "V-570" photospectrometer, in situ transmittance spectra of $\mathrm{nc}-\mathrm{TiO}_{2}$ in $\mathrm{LiClO}_{4}+\mathrm{PC}$ versus bias potential were recorded on the films of the working electrode mounted in a modified electrochemical cell which was placed under the pathway of the laser beam, and the three cell electrodes were connected to a potentiostat.

\section{Results and Discussion}

3.1. Electrochemical Deposition. Under an application of the potential of $-1.5 \mathrm{~V} / \mathrm{SCE}$, the fact that the current density was increased with the increase in time would prove that $\mathrm{W}^{6+}$ was inserted into the working electrode with a compensation of negative charges $\left(\mathrm{e}^{-}\right)$. Due to the bonding of $\mathrm{W}^{6+}$ with $\mathrm{O}^{2-}$ ions, $\mathrm{WO}_{3}$ was formed. This further was confirmed by XRD analysis (see the next section). From all the deposition experiments, it was seen that the current density increased fast and reached a saturate value in $40 \mathrm{sec}$ (Figure 1).

With this interval, the $\mathrm{WO}_{3}$ volume almost filled up the pores in the porous $\mathrm{TiO}_{2}$ film, and then stopped increasing at the saturate current density. However, the total time of $130 \mathrm{sec}$ for the deposition was chosen. The thickness of as-deposited $\mathrm{WO}_{3} / \mathrm{TiO}_{2}$ films, checked on the AlphaStep Pro-filer, was of $\sim 570 \mathrm{~nm}$. These films were slightly thicker than the initial doctor-blade nc- $\mathrm{TiO}_{2}$ films (namely $550 \mathrm{~nm})$. 


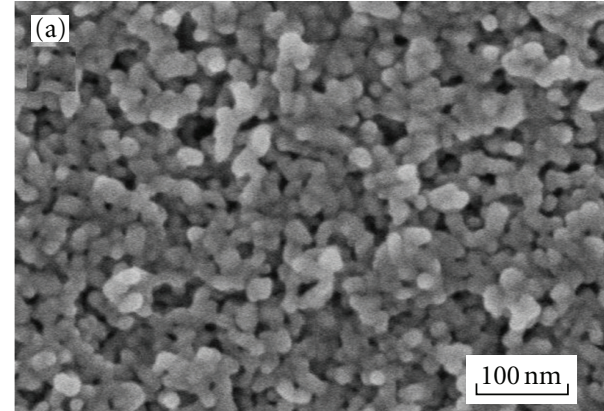

(a)

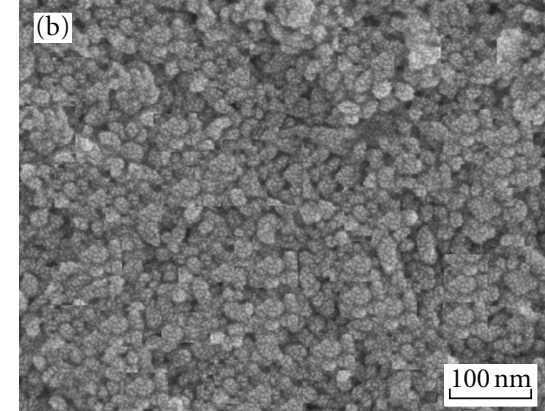

(b)

FIgURE 2: FE-SEM micrographs of as-prepared nc- $\mathrm{TiO}_{2}$ films (a) and after the electrochemical deposition process in a $\mathrm{H}_{2} \mathrm{~W}_{2} \mathrm{O}_{11}$ electrolyte (b).

3.2. Morphology and Crystalline Structure. In the doctorblade deposition, the thickness of the films was found to be depending on preparation conditions such as the concentration of solutions and the spread speed. The samples used for further investigation were taken from films chosen with a concentration of $5 \mathrm{wt} \% \mathrm{TiO}_{2}$ in water and a spread speed of $8 \mathrm{~mm} / \mathrm{s}$. A bright-field micrograph of the film surface is shown in Figure 2(a). The film is quite uniform, but some crystallized nanoparticles are a little larger than the initial $\mathrm{TiO}_{2}$ particles dispersed in water (namely $20 \mathrm{~nm}$ in size). The thickness of the films was of ca. $550 \mathrm{~nm}$. In comparison with the nanostructured films prepared by sol-gel method [7], these films are thicker and much more porous. Thus, between the nc- $\mathrm{TiO}_{2}$ particles, there are numerous nanoscale pores which would favour the insertion of ions like $\mathrm{Li}^{+}, \mathrm{Na}^{+}$, and/or $\mathrm{W}^{6+}$ into the films, when a polarized potential is applied on the working electrode (nc- $\mathrm{TiO}_{2} /$ FTO). With the insertion of the $\mathrm{Li}^{+}$, one can obtain the ECD coloration, whereas the insertion of $\mathrm{W}^{6+}$ during the electrochemical deposition would result in the insertion of $\mathrm{WO}_{3}$ nanoparticles into the pores of the nanostructured $\mathrm{TiO}_{2}$ film. Figure 2(b) shows the FE-SEM of the surface of the $\mathrm{TiO}_{2}$ electrode after the electrochemical process in the $\mathrm{H}_{2} \mathrm{~W}_{2} \mathrm{O}_{11}$ solution. During the deposition, we observed that the $\mathrm{TiO}_{2} /$ FTO electrode was coloured and became deep-blue with the increase in the deposition time. This coloration can be attributed to the insertion of $\mathrm{W}^{6+}$ (the ions from the $\mathrm{H}_{2} \mathrm{~W}_{2} \mathrm{O}_{11}$ electrolyte) into the $\mathrm{TiO}_{2}$ films according to the following equation:

$$
\mathrm{TiO}_{2} \text { (transparent) }+\mathrm{xW}^{3+}+\mathrm{xe}^{-} \longrightarrow \mathrm{W}_{\mathrm{x}} \mathrm{TiO}_{2} \text { (blue), }
$$

where $\mathrm{W}^{6+}$ plays the role of $\mathrm{Li}^{+}$in the well-known equation [10]:

$$
\mathrm{TiO}_{2}(\text { transparent })+\mathrm{x}\left(\mathrm{Li}^{+}+\mathrm{e}^{-}\right) \longrightarrow \mathrm{Li}_{\mathrm{x}} \mathrm{TiO}_{2} \text { (blue) } .
$$

From our previous work [11], it was shown that an electrochromic $\mathrm{WO}_{3}$ film was deposited onto the FTO electrode by the electrochemical technique. Hereby, simultaneously with the EC coloration, one can deposit $\mathrm{WO}_{3}$ particles into
$\mathrm{TiO}_{2} / \mathrm{FTO}$ to form a film with heterojunctions of $\mathrm{WO}_{3} / \mathrm{TiO}_{2}$ created from a mixture of $\mathrm{WO}_{3}$ and $\mathrm{TiO}_{2}$ nanoparticles. This would lead to the different features observed in the FE-SEM picture of the $\mathrm{WO}_{3} / \mathrm{TiO}_{2}$ film (Figure 2(b)) as compared to the FE-SEM picture for a nc- $\mathrm{TiO}_{2}$ film (Figure 2(a)).

The crystalline structure of the films was confirmed by using an accessory for films with a small angle of the X-ray incident beam. For such a thick film of nc- $\mathrm{TiO}_{2}$, all XRD patterns of the FTO substrate do not appear (Figure 3(a)). XRD patterns show all the diffraction peaks corresponding to titanium oxide. Indeed, for the doctor-blade film, in the XRD patterns, there are the most intense peak of the (101) direction corresponding to $d=0.352 \mathrm{~nm}$ and three smaller peaks corresponding to $0.238,0.190$, and $0.149 \mathrm{~nm}$. These diffraction peaks are quite consistent with the peaks for a single crystal of $\mathrm{TiO}_{2}$ anatase.

The fact that the peak width is rather small shows that the $\mathrm{TiO}_{2}$ anatase film was crystallized into large grains. To obtain the grain size $\tau$, we used the Scherrer formula:

$$
\tau=\frac{0.9 \lambda}{\beta \cdots \cos \theta},
$$

where $\lambda$ is wavelength of the $\mathrm{X}$-ray used $(\lambda=0.154 \mathrm{~nm}), \beta$ the peak width of half height in radians and $\theta$ the Bragg angle of the considered diffraction peak [12]. From the XRD patterns, the half-height peak width of the (101) direction was found to be $\beta=0.005$, consequently, the size of (101) grain was determined as $\tau \approx 20 \mathrm{~nm}$. Similarly, the size for the other grains was found to be from 25 to $30 \mathrm{~nm}$. This is in good agreement with data obtained by FE-SEM for the average size of particles where the crystalline grains were not identified by the Miller indexes (see Figure 2(a)).

The XRD patterns of the $\mathrm{WO}_{3} / \mathrm{TiO}_{2}$ (Figure 3(b)) possess both the peaks of $\mathrm{TiO}_{2}$ and $\mathrm{WO}_{3}$, where one peak of (004) direction of $\mathrm{TiO}_{2}$ was not revealed and relative intensity of the peaks changed a little bit. This is due to the presence of $\mathrm{WO}_{3}$ particles, whose average size, estimated by formula (1), is the same as the size of pores. This result, together with the observation of the FE-SEM pictures (Figure 1), demonstrates that $\mathrm{WO}_{3}$ particles were indeed filling-up the nanopores of the porous nc- $\mathrm{TiO}_{2}$ film. 


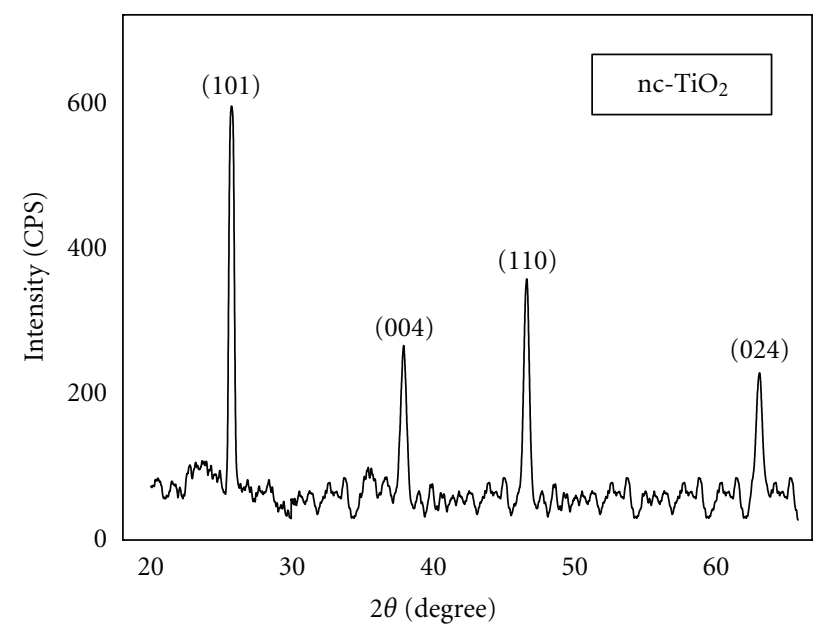

(a)

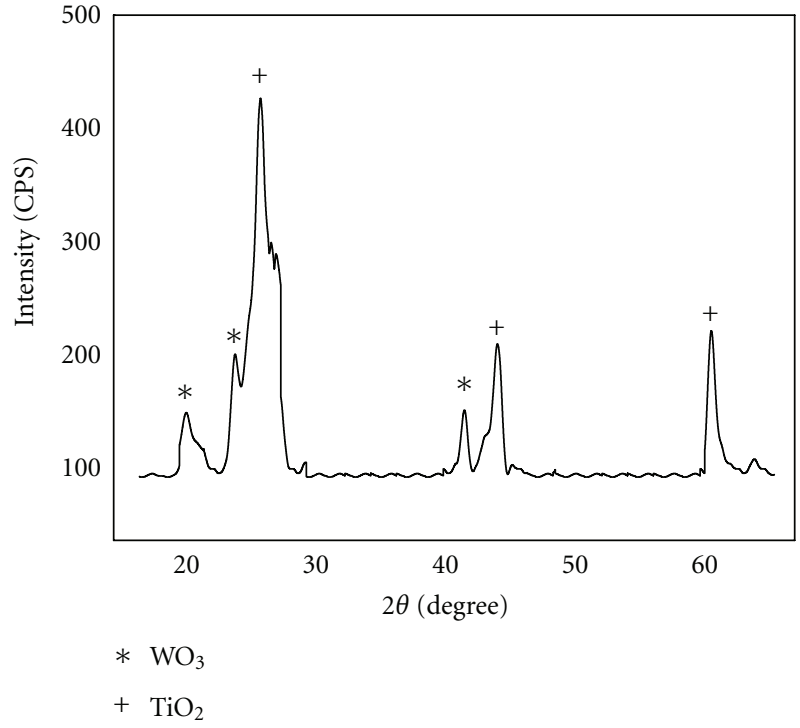

(b)

Figure 3: $\mathrm{XRD}$ of a nc- $\mathrm{TiO}_{2}$ doctor-blade film (a) and of a $\mathrm{WO}_{3} / \mathrm{TiO}_{2}$ film coated by electrochemical deposition.

3.3. Electrochemical Property. Figure 4 presents a chronoamperometric plot obtained by setting up five lapses of $5 \mathrm{sec}$ for the coloration and bleaching, corresponding to $-1.50 \mathrm{~V} / \mathrm{SCE}$ and to $+1.50 \mathrm{~V} / \mathrm{SCE}$, respectively. To calculate the inserted charge $(Q)$ for the coloration state, we use the formula for integrating between the starting and ending times of each lapse of time as follows:

$$
Q=\int_{t_{1}}^{t_{2}} J(t) d t
$$

The insertion charge was found to be $Q_{\text {in }}=21 \mathrm{mC} \times$ $\mathrm{cm}^{-2}$, whereas for the extraction process the charge was $Q_{\mathrm{ex}}$ $=19 \mathrm{mC} \times \mathrm{cm}^{-2}$, that is slightly different from the insertion charge. The fact that the insertion and extraction charges are similar proves the reversibility of the electrochromic coloration/bleaching process-a desired characteristic for the electrochromic performance of the $\mathrm{WO}_{3} / \mathrm{TiO}_{2}$-based electrochromic devices.

Figure 5 shows the cyclic voltammetry $(\mathrm{CV})$ spectra of a $\mathrm{WO}_{3} / \mathrm{TiO}_{2} / \mathrm{FTO}$ electrode cycled in $1 \mathrm{M} \mathrm{LiClO}_{4}+\mathrm{PC}$. In the positive scanning direction (PSD) there are two peaks of the current density at potentials of $-1.0 \mathrm{~V} / \mathrm{SCE}$ and at $-0.32 \mathrm{~V} /$ SCE. In the negative scanning direction (NSD) there are also two similar peaks. This proves the reversibility of the insertion/extraction of $\mathrm{Li}^{+}$into/out of the $\mathrm{WO}_{3} / \mathrm{TiO}_{2} / \mathrm{FTO}$ electrode. Moreover, the CV spectra of the $\mathrm{WO}_{3} / \mathrm{TiO}_{2} / \mathrm{FTO}$ electrode possess a different characteristic from the one of each compound for either $\mathrm{WO}_{3} / \mathrm{FTO}$ or $\mathrm{TiO}_{2} / \mathrm{FTO}$. These $\mathrm{CV}$ spectra can be seen as just the $\mathrm{CV}$ of a mixture of $\mathrm{WO}_{3}$ and $\mathrm{TiO}_{2}$ electrodes cycled simultaneously in $\mathrm{LiClO}_{4}+\mathrm{PC}$ electrolyte.

Therefore the electrochromic performance of the $\mathrm{WO}_{3} /$ $\mathrm{TiO}_{2} / \mathrm{FTO}$ electrode in $\mathrm{LiClO}_{3}+\mathrm{PC}$ can be described by two

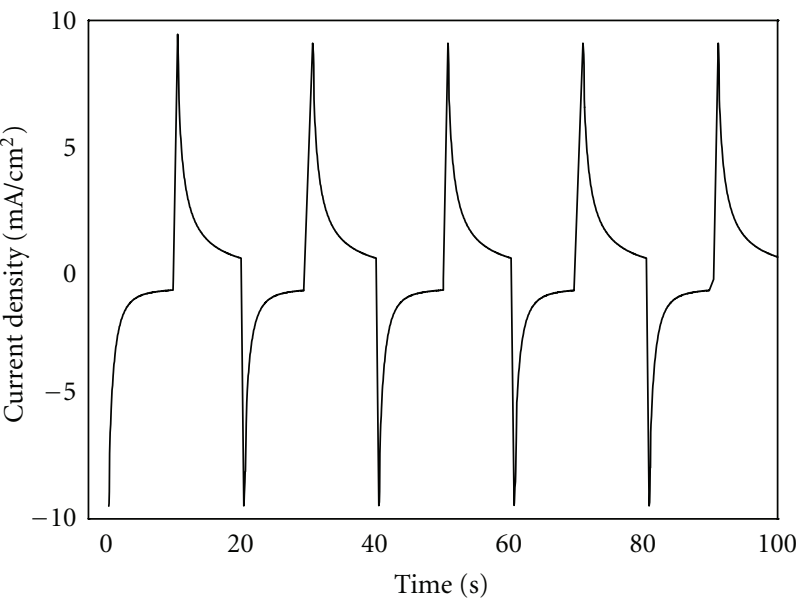

Figure 4: Insertion and extraction of $\mathrm{Li}^{+}$ions into/out of the $\mathrm{WO}_{2} /$ $\mathrm{TiO}_{2} /$ FTO electrode. The inserted charge (a bottom half cycle) of the saturated coloration state and the completely bleaching state (a top half cycle), respectively, are $Q_{\text {in }}=21 \mathrm{mC} \times \mathrm{cm}^{-2}$ and $Q_{\mathrm{ex}}=$ $19 \mathrm{mC} \times \mathrm{cm}^{-2}$.

cathodic reactions; one is $[13,14]$ :

$$
\mathrm{WO}_{3}+\mathrm{x}\left(\mathrm{Li}^{+}+\mathrm{e}^{-}\right) \longleftrightarrow \mathrm{Li}_{\mathrm{x}} \mathrm{WO}_{3}
$$

and the other one is reaction (2).

3.4. Electrochromic Performance. For a sample with a $570 \mathrm{~nm}$ thick $\mathrm{WO}_{3} / \mathrm{TiO}_{2}$ film, the in situ transmission spectra, obtained during coloration at a polarized potential of $-1.2 \mathrm{~V} / \mathrm{SCE}$ are given in Figure 6.

Figure 6 shows the transmittance of a $570 \mathrm{~nm}$ thick $\mathrm{WO}_{3} / \mathrm{TiO}_{2}$ film in $1 \mathrm{M} \mathrm{LiClO}_{4}+\mathrm{PC}$ at different polarizing bias potentials (from $-0.5 \mathrm{~V} / \mathrm{SCE}$ to $+0.3 \mathrm{~V} / \mathrm{SCE}$ ). From this 




Figure 5: Cyclic voltammetry spectra of $\mathrm{WO}_{3} / \mathrm{TiO}_{2} / \mathrm{FTO}$ cycled in $\mathrm{LiClO}_{4}+\mathrm{PC}$ (scanning rate $v=100 \mathrm{mV} / \mathrm{s}$ ).

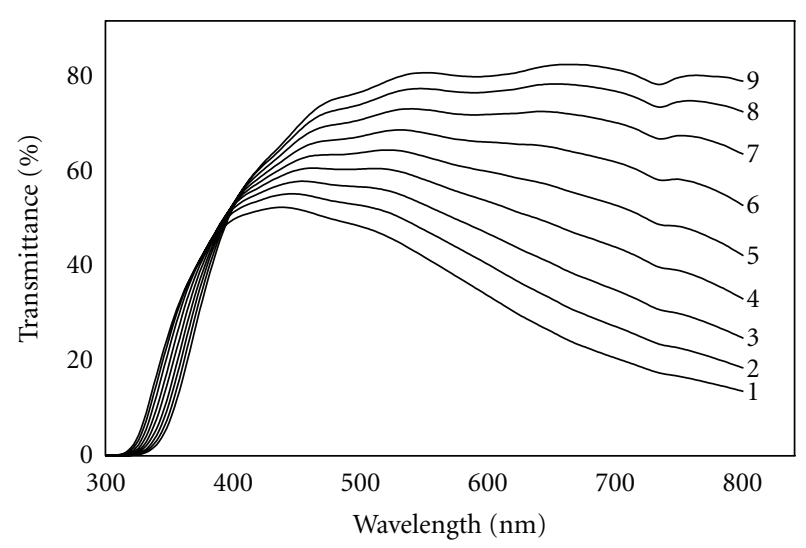

Figure 6: Transmittance spectra of the $\mathrm{WO}_{3}$ film filled in $1 \mathrm{M}$ $\mathrm{LiClO}_{4}+\mathrm{PC}$ solution with polarized potential ranging from $-0.5 \mathrm{~V} / \mathrm{SCE}$ to $+0.3 \mathrm{~V}$. Curves $1,2,3,4,5,6,7,8$, and 9 correspond, respectively, to $-0.5,-0.4,-0.3,-0.2,-0.1,0,+0.1,+0.2$, and $+0.3 \mathrm{~V} / \mathrm{SCE}$.

figure, one can see a large difference in transmittance spectra in the visible range of the film between the colored (curve 1) and bleached (curve 9) states. The transmittance at $\lambda=$ $550 \mathrm{~nm}$ (the sensitivity peak of human eye) from $\sim 85 \%$ with the bleached state decreased to $40 \%$ with the colored state, corresponding respectively to bias potential from $+0.3 \mathrm{~V} / \mathrm{SCE}$ to $-0.5 \mathrm{~V} / \mathrm{SCE}$. This result indicates that the electrochemically deposited $\mathrm{WO}_{3} / \mathrm{TiO}_{2}$ films exhibited an excellent EC performance that can be comparable to the one of the cosputtered Ti-doped $\mathrm{WO}_{3}$ films, as reported in [3]. The transmittance decreases with the increasing of the bias potential in NSD interval.

The bleaching and coloration processes were measured under the application of negatively and positively polarized voltage to the working electrode, respectively. These processes were clearly associated with the $\mathrm{Li}^{+}$insertion (extraction) from the $\mathrm{LiClO}_{4}+\mathrm{PC}$ electrolyte into (out of) the $\mathrm{WO}_{3} / \mathrm{TiO}_{2} / \mathrm{FTO}$ electrode. In comparison with results

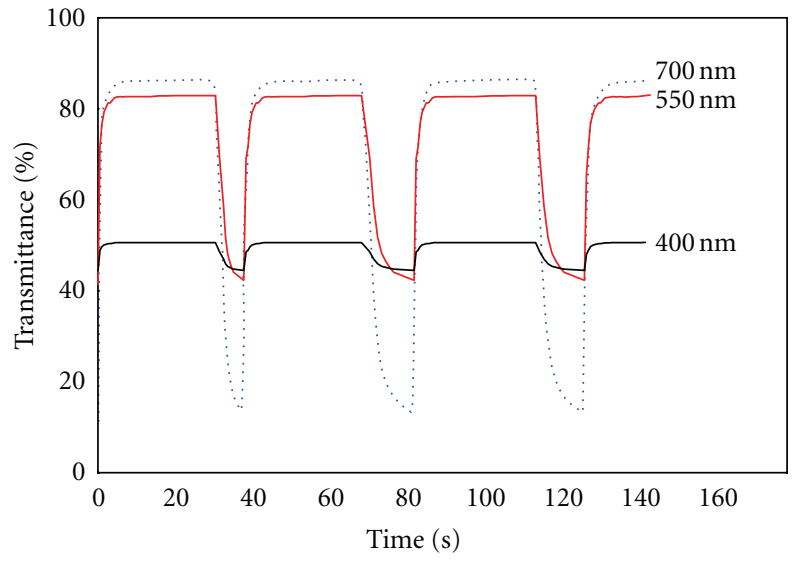

Figure 7: Time-dependence transmittance of the $\mathrm{WO}_{3} / \mathrm{TiO}_{2} / \mathrm{FTO}$ during electrochromic performance for three different wavelengths: 400, 550, and $700 \mathrm{~nm}$.

reported previously [8], the optical modulation at the visible range for $\mathrm{WO}_{3} / \mathrm{TiO}_{2} / \mathrm{FTO}$ at longer wavelengths is improved. Herein, we attained a transmittance at $\lambda=550 \mathrm{~nm}\left(\mathrm{~T}_{550}\right)$ equal to $84 \%$ upon bleaching and to $42 \%$ after a coloration period of $30 \mathrm{~s}$. The largest optical modulation in the visible range was observed for red light $\left(\mathrm{T}_{700}\right)$ as seen in Figure 7: the gap between the transmittances of bleaching and coloration states was of $70 \%$. For blue light $\left(\mathrm{T}_{400}\right)$, the optical modulation at wavelength $400 \mathrm{~nm}$ was negligible, that is about $5 \%$. This would result from the strong absorption by both $\mathrm{WO}_{3}$ and $\mathrm{TiO}_{2}$ at shorter wavelengths.

From the above-mentioned results for the ECDs with heterojunctions of $\mathrm{WO}_{3} / \mathrm{nc}-\mathrm{TiO}_{2}$, it is seen that the efficient coloration can be achieved due to a double-coloration process, such as shown in (2) and (5). To evaluate the electrochromic coloration efficiency $(\eta)$ we used a well-known expression relating the efficiency with the optical density $(\Delta \mathrm{OD})$, consequently the transmittances of coloration $\left(T_{c}\right)$ and bleaching states $\left(T_{b}\right)$, and the insertion charge $(Q)$, as follows [15]:

$$
\eta=\frac{\Delta \mathrm{OD}}{Q}=\frac{1}{Q} \ln \left(\frac{T_{b}}{T_{c}}\right) .
$$

At a wavelength of $550 \mathrm{~nm}, Q_{\text {in }}=21 \mathrm{mC} \times \mathrm{cm}^{-2}, T_{b}=$ $85 \%$ and $T_{c}=40 \%$, the coloration efficiency was determined to be $35.7 \mathrm{~cm}^{2} \times \mathrm{C}^{-1}$. The larger the wavelength is, the higher the coloration efficiency is. In the visible range of wavelengths, all the found values of $\eta$ are comparable to those for $\mathrm{WO}_{3}$ films [16] and much higher than those for $\mathrm{TiO}_{2}$ films [7] prepared by sol-gel techniques and titanium-lanthanide oxides deposited by magnetron sputtering and coloured in a $\mathrm{LiClO}_{4}+\mathrm{PC}$ solution [17].

To investigate the ageing process of two types of electrochromic devices, the first one is made from $\mathrm{nc}^{-\mathrm{TiO}_{2}}$ and the second one from $\mathrm{WO}_{3} / \mathrm{nc}-\mathrm{TiO}_{2}$ electrode, we measured the optical density versus bias potential after cycling these electrodes in $1 \mathrm{M} \mathrm{LiClO}_{4}+\mathrm{PC}$ for $10^{3}$ cycles. At a fixed wavelength, the larger is the difference between $T_{c}(\lambda)$ of the colored state and $T_{b}(\lambda)$ of the bleached state, the higher is 


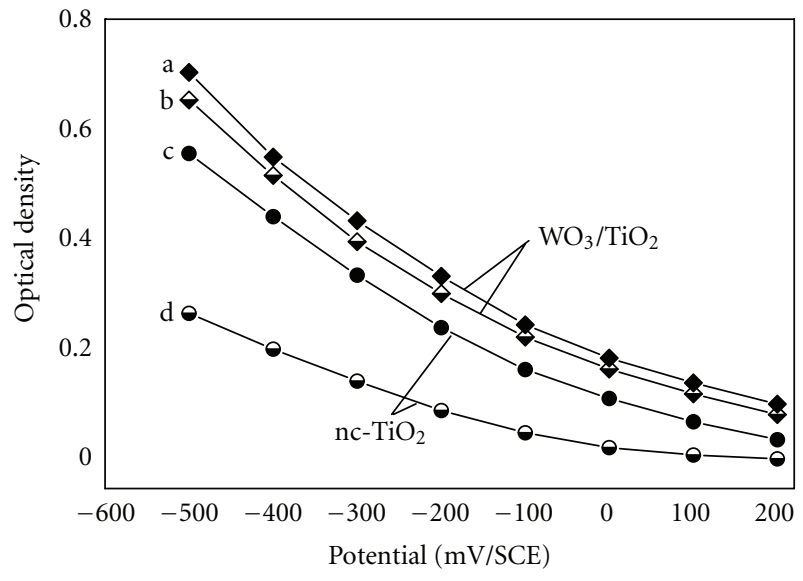

FIGURE 8: The potential dependence of the optical density of nc$\mathrm{TiO}_{2} / \mathrm{FTO}$ (two bottom curves) and $\mathrm{WO}_{3} / \mathrm{TiO}_{2} / \mathrm{FTO}$ (two top curves) electrodes during electrochromic performance in $1 \mathrm{M} \mathrm{LiClO}_{4}$ + PC for as-prepared $(\mathrm{a} ; \mathrm{c})$ and after cycling for $10^{3}$ cycles $(\mathrm{b} ; \mathrm{d})$.

the value of $\triangle \mathrm{OD}$. The potential dependence of $\Delta \mathrm{OD}$ at $\lambda=550 \mathrm{~nm}$ for two above-mentioned electrodes is shown in Figure 8. From this figure, we can see that for both the mentioned electrodes, the best optical density has been found for the bias potential of $-0.5 \mathrm{~V} / \mathrm{SCE}$. At this potential, the largest number of $\mathrm{Li}^{+}$cations would be inserted into the electrodes making the $\mathrm{TiO}_{2}$ and $\mathrm{WO}_{3}$ structures change to $\mathrm{Li}_{x} \mathrm{TiO}_{2}$ to $\mathrm{Li}_{x} \mathrm{WO}_{3}$, respectively. The number of colour centers (namely $\mathrm{Li}_{x} \mathrm{TiO}_{2}$ and $\mathrm{Li}_{x} \mathrm{WO}_{3}$ ) is dependent on the number of $\mathrm{Li}^{+}$cations and electrons injected into the electrodes. In general, this number increases proportionally to the bias potential applied on the working electrode. The reason why the $\triangle \mathrm{OD}$ of the $\mathrm{nc}-\mathrm{TiO}_{2}$ based ECD decreased faster than that of $\mathrm{WO}_{3} / \mathrm{TiO}_{2}$ is revealed by the monitoring of the film thickness of the electrodes during the electrochromic performance. After $10^{3}$ cycles of the ECD performance, the thickness of both electrodes was checked with the Alpha step profiler, and it was found that a part of the nc- $-\mathrm{TiO}_{2}$ film was removed while the $\mathrm{WO}_{3} / \mathrm{nc}-\mathrm{TiO}_{2}$ was maintained almost unchanged. This demonstrates that $\mathrm{WO}_{3}$ attached to $\mathrm{TiO}_{2}$ particles enables the structure of $\mathrm{WO}_{3} / \mathrm{nc}-\mathrm{TiO}_{2}$ film to be much more strengthened. Thus the devices with $\mathrm{WO}_{3} / \mathrm{TiO}_{2}$ nano-heterojunctions would possess a larger ECD lifetime.

\section{Conclusion}

Mixed nanostructured Ti-W oxides films were prepared by electrochemical deposition of $\mathrm{WO}_{3}$ onto doctor-blade nc$\mathrm{TiO}_{2} / \mathrm{FTO}$ films. Electrochromic performance studies of both the nc- $\mathrm{TiO}_{2} / \mathrm{FTO}$ and $\mathrm{WO}_{3} / \mathrm{TiO}_{2} / \mathrm{FTO}$ configurations were carried out in $1 \mathrm{M} \mathrm{LiClO}_{4}+$ propylene carbonate. The reversible coloration and bleaching process of $\mathrm{WO}_{3} / \mathrm{TiO}_{2}$ based electrochromic devices was demonstrated. The response time of the ECD coloration of $\mathrm{WO}_{3} / \mathrm{TiO}_{2} / \mathrm{FTO}$ was found to be as small as $2 \mathrm{~s}$ and the coloration efficiency could be as high as $35.7 \mathrm{~cm}^{2} \times \mathrm{C}^{-1}$. In situ transmittance spectra of the $\mathrm{WO}_{3} / \mathrm{TiO}_{2} / \mathrm{FTO}$ working electrode showed the insertion/extraction of $\mathrm{Li}^{+}$ions into/out of the electrode. By incorporating $\mathrm{WO}_{3}$ inserted between $\mathrm{TiO}_{2}$ nanoparticles, $\mathrm{WO}_{3} / \mathrm{TiO}_{2}$ heterojunctions were formed in the films. The resulting nanostructured film enables both the coloration efficiency and electrochemical stability of the working electrodes to be considerably improved.

Since a large-area $\mathrm{WO}_{3} / \mathrm{TiO}_{2}$ electrode can be prepared by the doctor-blade method, followed by an electrochemical deposition, this type of electrode constitutes a good candidate for smart window applications, taking advantage of its excellent properties in terms of EC efficiency and electrochemical stability, as well as the simplicity of the fabrication process.

\section{Acknowledgment}

This work was supported by the MOST of Vietnam through the Project on Fundamental Scientific Research for Applications; code: 1/2010/HD-DTNCCBUD (2010-2013).

\section{References}

[1] C. G. Granqvist, Handbook of Inorganic Electrochromic Materials, Elsevier, Amsterdam, The Netherlands, 1995.

[2] C. G. Granqvist, A. Azens, P. Heszler, L. B. Kish, and L. Österlund, "Nanomaterials for benign indoor environments: electrochromics for "smart windows", sensors for air quality, and photo-catalysts for air cleaning," Solar Energy Materials and Solar Cells, vol. 91, no. 4, pp. 355-365, 2007.

[3] A. Karuppasamy and A. Subrahmanyam, "Studies on electrochromic smart windows based on titanium doped $\mathrm{WO}_{3}$ thin films," Thin Solid Films, vol. 516, no. 2-4, pp. 175-178, 2007.

[4] L. Meda, R. C. Breitkopf, T. E. Haas, and R. U. Kirss, "Investigation of electrochromic properties of nanocrystalline tungsten oxide thin film," Thin Solid Films, vol. 402, no. 1-2, pp. 126-130, 2002.

[5] N. Naseri, R. Azimirad, O. Akhavan, and A. Z. Moshfegh, "Improved electrochromical properties of sol-gel $\mathrm{WO}_{3}$ thin films by doping gold nanocrystals," Thin Solid Films, vol. 518, no. 8, pp. 2250-2257, 2010.

[6] G. Beydaghyan, G. Bader, and P. V. Ashrit, "Electrochromic and morphological investigation of dry-lithiated nanostructured tungsten trioxide thin films," Thin Solid Films, vol. 516, no. 8, pp. 1646-1650, 2008.

[7] N. N. Dinh, N. T. T. Oanh, P. D. Long, M. C. Bernard, and A. H. L. Goff, "Electrochromic properties of $\mathrm{TiO}_{2}$ anatase thin films prepared by a dipping sol-gel method," Thin Solid Films, vol. 423, no. 1, pp. 70-76, 2003.

[8] N. Nang Dinh, N. Minh Quyen, D. N. Chung, M. Zikova, and V. V. Truong, "Highly-efficient electrochromic performance of nanostructured $\mathrm{TiO}_{2}$ films made by doctor blade technique," Solar Energy Materials and Solar Cells, vol. 95, no. 2, pp. 618623, 2011.

[9] E. A. Meulenkamp, "Mechanism of $\mathrm{WO}_{3}$ electrodeposition from peroxy-tungstate solution," Journal of the Electrochemical Society, vol. 144, no. 5, pp. 1664-1671, 1997.

[10] G. Campet, J. Portier, S. J. Wen, B. Morel, M. Bourrel, and J. M. Chabagno, "Electrochromism and electrochromic windows," Active and Passive Electronic Components, vol. 14, pp. 225-231, 1992. 
[11] P. D. Long, N. N. Dinh, M. C. Bernard, and A. H. Le Goff, "Preparation and study of electrochromic properties of tunsten oxides films made by electrochemical method," Vietnam Communications in Physics, vol. 10, no. 3, pp. 164-170, 2000.

[12] B. D. Cullity, Elements of X-Ray Diffraction, Addison-Wesley, Reading, Mass, USA, 2nd edition, 1978.

[13] Y. Shigesato, "Photochromic properties of amorphous $\mathrm{WO}_{3}$ films," Japanese Journal of Applied Physics, vol. 30, no. 7, pp. 1457-1462, 1991.

[14] S. I. C. de Torresi, A. Gorenstein, R. M. Torresi, and M. V. Vázquez, "Electrochromism of $\mathrm{WO}_{3}$ in acid solutions: an electrochemical, optical and electrogravimetric study," Journal of Electroanalytical Chemistry, vol. 318, no. 1-2, pp. 131-144, 1991.

[15] P. M. S. Monk, R. J. Mortimer, and D. R. Rosseinsky, Electrochromism: Fundamentals and Applications, Wiley-VCH, Weinheim, Germany, 1995.

[16] P. Delichère, P. Falaras, and A. Hugot-Le Goff, " $\mathrm{WO}_{3}$ anodic films in organic medium for electrochromic display devices," Solar Energy Materials, vol. 19, no. 3-5, pp. 323-333, 1989.

[17] L. Kullman, A. Azens, and C. Granqvist, "Decreased electrochromism in Li-intercalated Ti oxide films containing La, Ce, and Pr," Journal of Applied Physics, vol. 81, no. 12, pp. 80028010, 1997. 

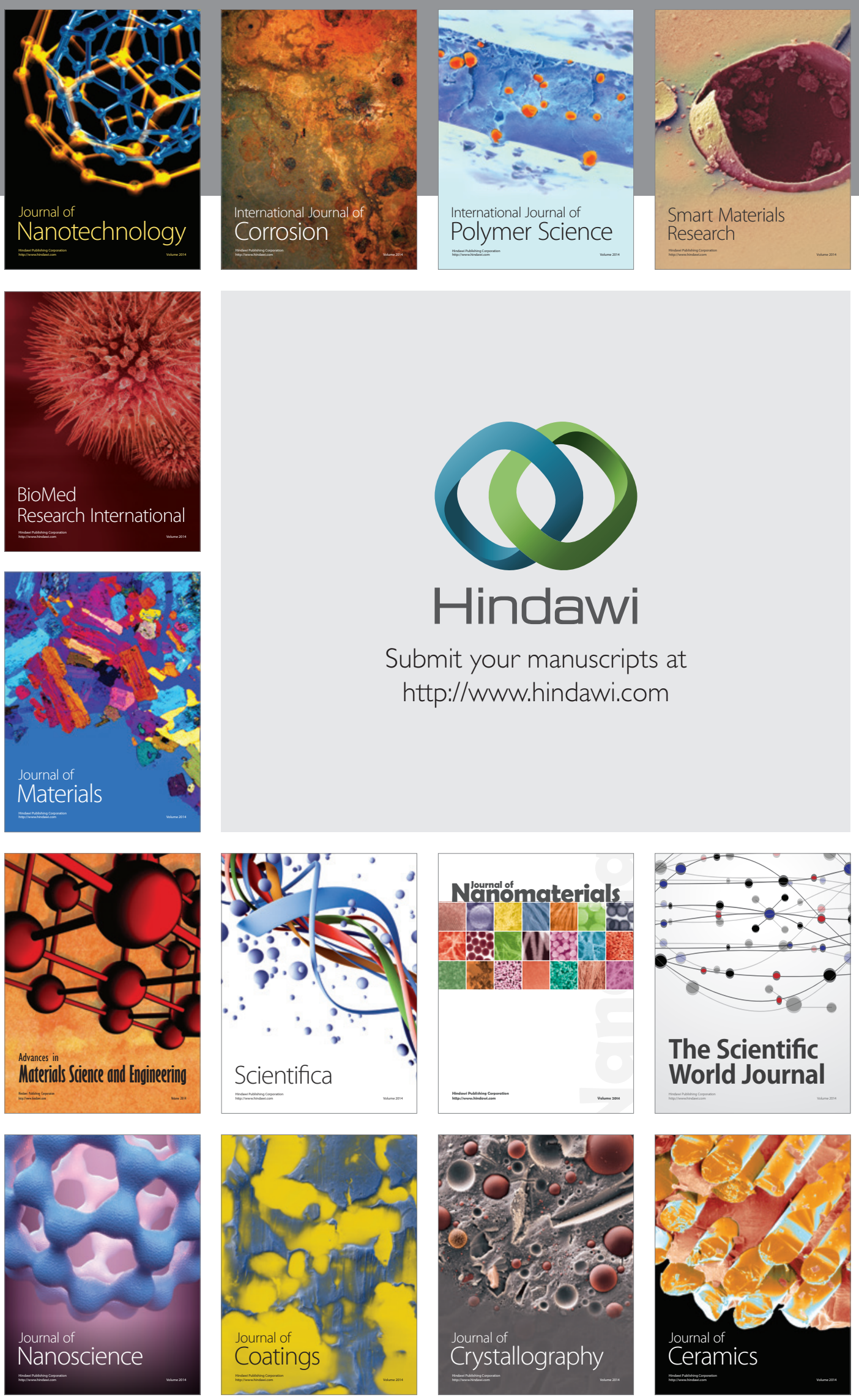

The Scientific World Journal

Submit your manuscripts at

http://www.hindawi.com

\section{World Journal}

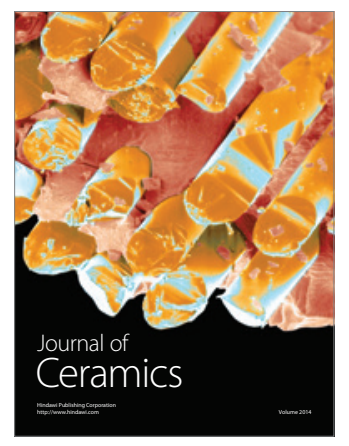

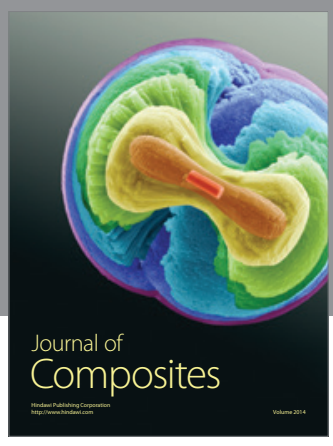
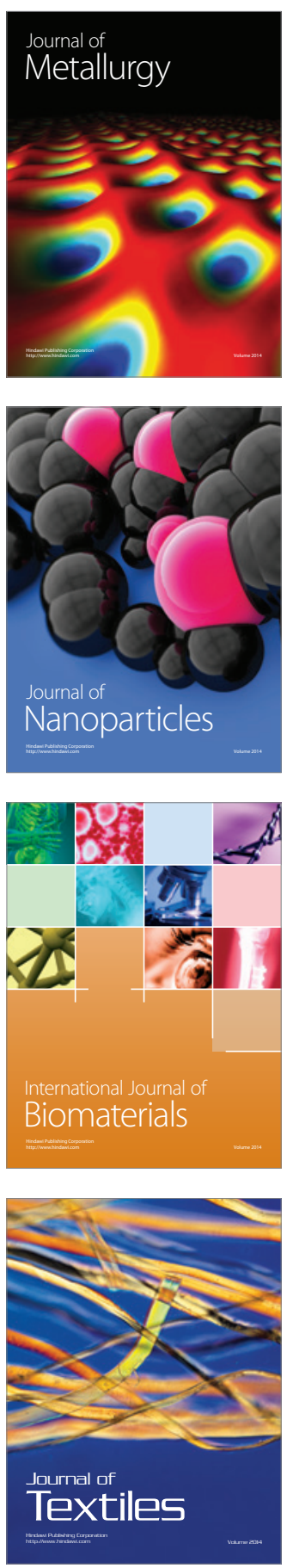